\title{
FACTORS AFFECTING THE PERFORMANCE OF HAJJ FUND INVESTMENT IN MALAYSIA
}

\author{
Sayyidah Ummu Sayyidah ${ }^{*}$, Prayogo P Harto ${ }^{2}$, Ahmad Baehaqi ${ }^{3}$, Edy Suprapto 4 \\ 1,2,3,4 Sekolah Tinggi Ekonomi Islam SEBI \\ E-mail: aidasyahidah.sus@gmail.com (correspondence author)
}

\begin{abstract}
This study aims to analyze the effect of Investment Costs, Investment Size and Asset Allocation Policy on Investment Performance of Hajj Funds in Malaysia. The method used in this study is a quantitative method with Malaysia Hajj Financial Report Financial Data for 2008 - 2017 and data analysis techniques using non-parametric linear regression analysis with theil method. The results of this study indicate that all three factors together have a significant effect on the investment performance of Hajj funds. However, only Investment Costs are significant to the Investment Performance of the Hajj Fund. While the Investment Size and Asset Allocation Policy are not significant to the Investment Performance of the Hajj Fund in Malaysia.
\end{abstract}

Keywords: Investment Performance, Hajj Funds Investment, Investment Cost, Investment Size, Asset 


\section{Introduction}

According to Media Indonesia, the Muslim population in the world in 2019 will be around 1.8 billion. This amount resulted in the occurrence of the hajj waiting list for decades("Jumlah Populasi Muslim Dunia (Total World Muslim Population)" 2019, Media Indones.). The line of pilgrimage to Malaysia was 121 years long. In addition, Saudi Arabia itself limits the quota for Hajj. In 2019 Malaysian hajj quota of 30,200 worshipers ("Antrean Masa Tunggu Haji Di Malaysia Hingga 121 Tahun (The Queve Waiting Period for Pilgrimage in Malaysia to 121 Years)" 2019, Minist. Relig.)

To perform the Hajj, the community is certainly charged. The cost of hajj in Malaysia is 9,980 ringgit or around US \$2,400 for regular hajj ("Antrean Masa Tunggu Haji Di Malaysia Hingga 121 Tahun (The Queve Waiting Period for Pilgrimage in Malaysia to 121 Years)" 2019, Minist. Relig.). The large amount of costs caused the Islamic Bank in Malaysia to create a Hajj savings product. So that the pilgrimage savings fund does not settle just like that and cause a decrease in value, the government is looking for a solution in the form of haj investment investment management (Salatalohy and Wibowo 2019)

Under the Malaysian Act Deed 535 "1995 Hajj Tube Deed", the Hajj fund is administered by the Hajj Tube Institution (TH). TH functions to manage the pilgrimage fund, manage all matters relating to the welfare of pilgrims and to formulate a basis relating to it (Malaysia Law: Akta 535 "Akta Tabung Haji 1995" 2014, Undang-Undang Malaysia). TH institutions experienced a decrease in profits in 2016 amounted to RM 1,050 Million.

Based on the financial report data of the Hajj in 2008 to 2017, for the field of investment alone in 2009 and 2012 investment has decreased but investment income continues to increase. But in 2014 and 2015 when investment increased, investment income declined. Decrease in profits or investment income is certainly influenced by several factors.

According to (Nugraha 2016)factors affecting investment performance include the size of the fund, the age of investment and the operating costs of the investment. Meanwhile, according to (Paramitha and Purnawati 2017), investment performance is influenced by the performance of investment managers and asset allocation policies. In addition, according to (Bitomo and Muharam 2016), factors that influence investment performance are past performance, fund size, fund age, expense ratio, and fund cash flow.

Research (Putra 2014)factors that affect the performance of stock mutual funds, namely the size of the mutual fund, the policy of allocation of stock assets, the cost of investment managers and the age of the mutual fund. Of the several factors above, there are several factors that tend to be dominant factors, namely cost, size, and asset allocation policy. So the authors take the independent variable investment cost, investment size, and asset allocation policies.

This research takes the object of Malaysia because Malaysia has a more experienced pilgrimage management institution compared to Indonesia. Malaysia's Haij Tubes has been established since 1963 while the Indonesian Hajj Financial Management Board was established in mid 2017. TH also has consistent achievements and has gained worldwide recognition. In addition $\mathrm{TH}$ is an example of the management of Haij and is an innovative manager of Islamic finance by most Islamic countries in the world ("Tabung Haji Malaysia: Penyimpan Dana Ibadah Haji Profesional Dan Berintegritas (Malaysian Hajj Tube: Professional and Integrity Pilgrimage Fund Depositors)" 2017, Muslim Go)

From this description, the problem in this study can be formulated in the form of a question: does investment cost, investment size, and asset allocation policy affect the investment performance of haj funds in Malaysia? The purpose of this study was to determine the effect of investment cost, investment size, and asset allocation policies on the investment performance of Hajj funds in Malaysia.

\subsection{Financial Management of Hajj}


Hajj finance consists of income, expenses and wealth. The principles in managing the pilgrimage finance include the principles of sharia, the principle of prudence, benefits, non-profit, transparent, and accountable (Indonesia Law No. 342014 , Undang-Undang Republik Indonesia). Under Malaysian Law: Deed of 535 of 2014 Hajj finance in Malaysia is managed by the Malaysian Hajj Tube Institution or commonly called the Hajj Tube.

\subsection{Investation}

Tandelilin (2010) states that "Investment is a commitment to a number of funds or other resources made at this time with the aim of obtaining a number of benefits in the future"(Tandelilin 2010). Investment is a commitment of a current amount of money for a certain period of time to get future payments that will compensate investors for (1) the time the funds are allocated, (2) the expected level of inflation during this time period, and (3) uncertainty future payments (Reilly and Brown 2011).

From some of the above understanding it can be concluded that investment is a commitment in the context of investing capital in the form of money to companies to get profits in the future. The investment objectives according to Tandelilin (2010) are a) to get a better life in the future, b) reduce the impact of inflation by investing, c) encouragement to save taxes(Tandelilin 2010).

The main reason people invest is to make a profit. In the context of investment management, the level of investment returns is called return. It is necessary to distinguish between expected returns and realized returns. The expected return is the level of return that investors anticipate in the future. While the return that occurs or the actual return is the level of return that has actually been obtained by investors (Tandelilin 2010).

According to Sudirman (2015) realization returns can be used as a measurement of company performance and can be used as a basis for determining future expectations and risks, while expected returns are expected that occur in the future and are still uncertain(Sudirman 2015).

\subsection{Investment in Islam}

Investment is part of economic activity (muamalah māliyah), so the figh rule used is the muamalah figh rule, which is "basically all forms of muamalah are permissible, unless there is an argument which forbids it." (Fatwa Nasional Sharia Council Indonesian Ulema Council No: 07/DSN-MUI/IV/2000 about Mudharabah Financing (Qiradh) 2000, FATWA DSN MUI).The concept of investment according to Islam (sharia) is an investment based on sharia principles, investment halal and avoiding practices of maysir, gharar, and usury (Peristiwo 2016). The legal basis for investment is in the QS. Al-Hasyr: 7

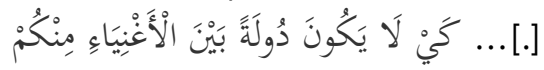

Meaning: "... So that the treasure does not circulate among rich people only among you ..." (Surah Al-Hasyr [59]: 7)

The principles of investment in Islam according to Aziz (2010)are:

1. Derived from halal rizki, both in terms of substances and how to get it, and not used for illicit things.

2. Not to wrong and not to be wronged.

3. Be fair in the distribution of income.

4. Transactions are carried out on the basis of pleasure and pleasure (an-taradin).

5. There is no element of usury, maysir / gambling / speculation and gharar (unclear ( vague).

(Aziz 2010)

An Islamic investment policy starts from the Shariah Board which assesses the suitability of the product and the way of investment with Islamic rules. There are two types of investments that are allowed in Islam Nadjib (2008), namely equity investments and fixed income funds(Nadjib 2008).

In addition, according to Nadjib (2008), Shariah investment funds must meet the 
following 2 criteria:

- Bringing pro-rated profits derived from these funds is not a fixed return. So that the capital or profit is not guaranteed.

- The funds collected are invested in companies that comply with sharia

\subsection{Investment Performance}

Investment performance is one of the most important factors for the success of banks, insurance companies and other financial institutions (Subramanyam and Wild 2010).Performance measurement is a management tool used to improve the quality of decision making and accountability and to assess the achievement of goals and objectives with key elements of planning and goal setting, development of relevant measures, formal reporting of results, and use of information (Nurtjahjo 2013)

Performance measurements are carried out to achieve efficiency and effectiveness in all company business processes (Darmasto, Kamaliah, and Agusti, n.d.). To measure company performance used a measurement tool in the form of financial ratios. According to Kasmir (2010)the types of financial ratios are:

a. The liquidity ratio or working capital ratio is the ratio used to measure how liquid a company is.

b. The Solvency Ratio (leverage ratio) is a ratio used to measure the extent to which a company's assets are financed by debt.

c. Activity Ratio is a ratio used to measure the level of efficiency in the utilization of company resources (sales, stocks, debt collection, etc.) or to assess a company's ability to carry out daily activities.

d. Profitability Ratio is a ratio to assess a company's ability to look for profits or profits in a certain period.

e. Growth Ratio is a ratio that illustrates the ability of companies to maintain its economic position in the midst of economic growth and business sectors.

f. Evaluation Ratio, which is a ratio that provides a measure of management's ability to create business market value above investment costs such as the ratio of stock prices to earnings and the ratio of stock market values to book values.

(Kasmir 2010)

\subsection{Investment Cost}

According to Jusuf in Zandra (2016) expenses (costs) are the costs of acquiring assets consumed or services used in the process of obtaining income. In the case of investment, cost is the cost of investment used to obtain a return (Zandra 2016). Before investing, investors also need to understand what types of costs are charged either directly or indirectly associated with an investment and how much the cost of each cost post (Ruhiyat 2016).

There are 3 main components of investment costs, namely costs that are borne by investment managers, costs that are borne by investment fund managers, and costs that are borne by investors. Costs that are borne by investment managers include the costs of preparing investment formation (costs for making investment contracts), notary services fees, legal consultants, public accountants, and investment management costs (Pratomo 2001).

Costs charged to investment fund managers include: investment manager services fees, custodian bank service fees, securities transaction fees, fees for public accountant services, notaries, legal consultants after investing operations, monthly report delivery fees, making and sending prospectus updates, and fees tax. While the costs charged to investors are the purchase costs (subscription / top up fees), selling costs (redemption fees) and switching costs (Pratomo 2001).

In this case the Malaysian Hajj Tubes Institution is an investor and manager of investment funds because the Malaysian Hajj Tubes Institution invests prospective pilgrims to various types of investments and manages the investment funds. So that the investment costs at these institutions are costs that are either directly or indirectly related to the investment process, namely administrative costs, other costs, tax fees and zakat. 


\subsection{Investment Size}

According to Bitomo and Muharam (2016) "the size of an investment is a reflection of the size of the investment based on managed funds that can be assessed from the amount of Total Net Assets (TNA) (Bitomo and Muharam 2016). TNA / Net Assets is obtained from the reduction of total assets against liabilities held ". The size of the managed fund shows the size of the assets managed in the investment or the growth in the size of the assets managed in the investment (Ruhiyat 2016). So, investment size is a measuring tool to determine the size of investment managed by a company.

\subsection{Asset Alocation Policy}

According to Tandelilin (2010)the asset allocation decision is the distribution of funds held in various asset classes available (stocks, bonds, real estate or foreign securities)(Tandelilin 2010). Whereas according to Ruhiyat (2016) asset allocation policy is an action to place the weight or proportion of investment in money market and capital market instruments or a mixture of both with certain composition (Ruhiyat 2016).

From these two understandings, it can be concluded that the asset allocation policy is the act of placing funds in the types of assets available. Although the specified asset allocation policies vary, in principle they both provide a higher level of investment returns compared to other investments with certain risks (Ruhiyat 2016). Determination of an optimal asset allocation will minimize the risks faced in investment so that the combination of the level of return and the level of risk will result in optimal investment performance (Paramitha and Purnawati 2017).

\subsection{Research Hypothesis}

$\mathrm{Hl}$ : Investment cost has a positive effect on the investment performance of the Hajj Fund in Malaysia

$\mathrm{H} 2$ : Investment size has a positive effect on the investment performance of the Hajj Fund in Malaysia

H3: The Asset Allocation Policy has a positive effect on the investment performance of the Hajj Fund in Malaysia

\section{Research Methods}

This type of research used in this study is associative with quantitative methods. The population in this study is the financial statements of Hajj fund management institutions located in Malaysia. For sampling in this study using a purposive sampling method. The sample selection criteria in this study are 10 years of continuous financial reports and are published on the Hajj Tube website. Then the sample in this study is the Malaysian Haij Financial Institution financial statements from 2008 to 2017.

This study uses secondary data types, namely data obtained indirectly or in other words through third parties. The data used in this study was sourced from the Malaysia Hajj Institutional Financial Report obtained from the official website of the agency, namely www.tabunghaji.gov.my.

Table 1.Operational Variable

\begin{tabular}{|c|c|c|c|c|}
\hline No. & \multicolumn{2}{|c|}{ Variable } & Size & Reference \\
\hline 1. & Dependent & $\begin{array}{l}\text { Investmen } \\
t \\
\text { Performan } \\
\text { ce }\end{array}$ & $\begin{array}{l}\text { Investment Income } \\
\text { Investment Average }\end{array}$ & $\begin{array}{l}\text { (Subramanyam, } 2017 \\
\text { Hidayati \& Baehaqi, } \\
\text { 2018) }\end{array}$ \\
\hline 2. & $\begin{array}{c}\text { Independen } \\
\dagger\end{array}$ & $\begin{array}{l}\text { Investmen } \\
\text { t Cost }\end{array}$ & $\begin{array}{c}\text { Total Investment Cost } \\
\text { Total Investment }\end{array}$ & $\begin{array}{c}\text { (Bodie, Kane, \& Marcus, } \\
\text { 2014, Putra, 2014) }\end{array}$ \\
\hline
\end{tabular}




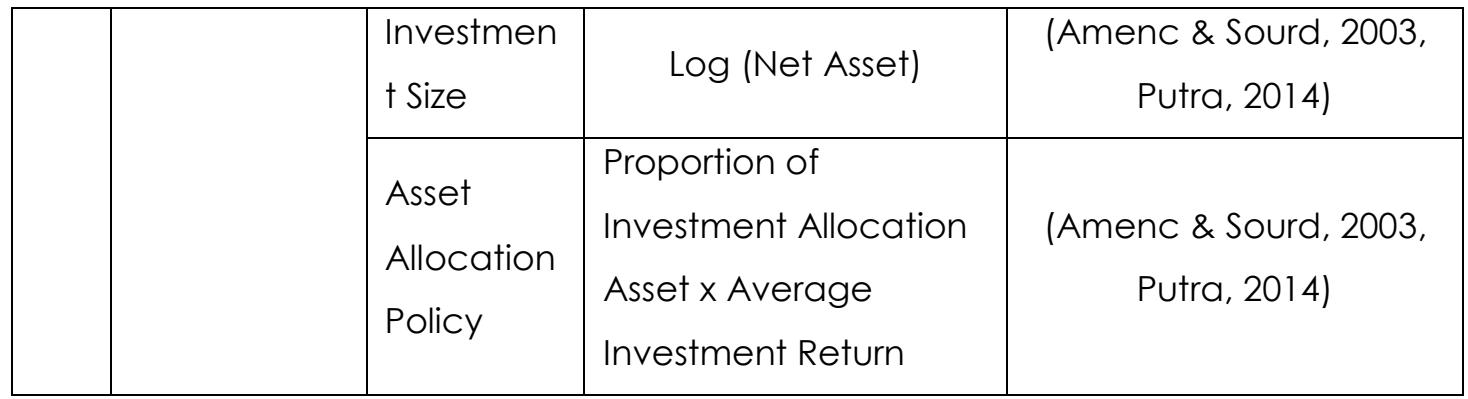

The data analysis method used in this study is the Theil method. Theil method is a nonparametric method used to estimate parameters and analyze linear regression lines with observed sample data because it is not spread normally. Nonparametric statistics are used for the amount of small sample data (Rahmatina 2011).

For one partner $\left(X_{i}, Y_{i}\right)$ and $\left(X_{j}, Y_{j}\right)$ the slope coefficients are:

$b_{i j}=y_{j}-y_{i}$

$x_{j}-x_{i}(1)$

Estimator for $b$ is denoted by $B$ expressed as the median of the bij values so that it is obtained:

$B=$ median (bij)

Whereas the estimator for a is A with

$A=\operatorname{med}(Y i-B$ med $(X i)$

Simple Linear Regression Model

$$
\begin{aligned}
& Y=a+b X 1+e \\
& Y=a+b X 2+e \\
& Y=a+b X 3+e(4)
\end{aligned}
$$

Where :

$Y=$ Investment Performance of Hajj Funds in Malaysi

$a=$ Constant

$B=$ Regression coefficient

$\mathrm{X} 1=$ Investment Cost

$\mathrm{X} 2=$ Investment Size

X3 - Asset Alocation Policy

$\mathrm{e}=$ Error standard

To test the regression coefficient statistical tests are used:

$\mathrm{Z}=\mathrm{T}-\mu \mathrm{T}$

бт

Where; $\mu T=0, \tau=$ correlation value knows

бт $=\sqrt{ } \frac{2(2 n+5)}{9 n(n-1)}$

The basis for decision making in this regression coefficient test is if the $z$ value is equal to 0 then there is no significant effect, but if the $z$ value is not equal to 0 then there is a significant influence (Rahmatina, 2011). 


\section{Result and Discussion}

\subsection{Determinant Coefissien}

In table 2, the $\mathrm{R}$ value of 0.924 shows that the correlation or the close relationship between the investment performance of the pilgrimage fund and the investment cost is very strong. Figures $R$ square (Coefficient of Determination) 0.854 means that $85.4 \%$ of the investment performance of the pilgrimage fund can be explained by the investment cost. While the rest of $100 \%-85.4 \%=14.6 \%$ is explained by other factors.

\section{Table 2. Investment Cost Determination Coefficient}

\begin{tabular}{ll|r|r|r} 
Model & R & R Square & $\begin{array}{c}\text { Adjusted R } \\
\text { Square }\end{array}$ & $\begin{array}{c}\text { Std. Error of } \\
\text { the Estimate }\end{array}$ \\
\hline 1 &, $924^{\text {a }}$ &, 854 &, 836 &, 037409 \\
\hline \multicolumn{2}{r}{ a. Predictors: (Constant). Investment Cost }
\end{tabular}

(Source: SPSS 25 Output Results (2020))

In the investment size (table 3 ), the $R$ value of 0.470 shows that the correlation or closeness of the relationship between the investment performance of the pilgrimage fund with the investment size is less strong because it is smaller than 0.5. Figures $R$ square (Coefficient of Determination) 0.221 means that $22.1 \%$ of the investment performance of the pilgrimage fund can be explained by the size of the investment. While the rest of $100 \%-22.1 \%=77.9 \%$ is explained by other factors.

Table 3.Investment Size Determination Coefficient

\begin{tabular}{lr|r|r|r} 
Model & $\mathrm{R}$ & R Square & $\begin{array}{c}\text { Adjusted } \mathrm{R} \\
\text { Square }\end{array}$ & $\begin{array}{c}\text { Std. Error of } \\
\text { the Estimate }\end{array}$ \\
\hline 1 &, $470^{\text {a }}$ &, 221 &, 123 &, 086420 \\
\hline \multicolumn{2}{c}{ a. Predictors: (Constant), Ukuran Investasi }
\end{tabular}

(Source: SPSS 25 Output Results (2020))

In the asset allocation policy (table 4) the $R$ figure of 0.583 shows that the correlation or closeness of the relationship between the investment performance of the pilgrimage fund with a strong investment size. While the determination coefficient of 0.340 means that $34.0 \%$ of the investment performance of the hajj funds can be explained by the size of the investment. While the rest of $100 \%-34.0 \%=66.0 \%$ is explained by other factors.

Table 4.Asset Alocation Policy Determination Coeffitient

\begin{tabular}{ll|r|r|r} 
Model & $R$ & R Square & $\begin{array}{c}\text { Adjusted R } \\
\text { Square }\end{array}$ & $\begin{array}{c}\text { Std. Error of } \\
\text { the Estimate }\end{array}$ \\
\hline 1 & $.583^{\text {a }}$ &, 340 &, 258 &, 079527 \\
\hline \multicolumn{3}{l}{ a. Predictors: (Constant), Kebijakan Alokasi Aset }
\end{tabular}

(Source: SPSS 25 Output Results (2020))

Standard Error Estimate (SEE) in table 4.2 0.037409 shows the error rate of the simple investment cost regression model, the smaller the SEE number, the smaller the error rate so that the simple regression model is more precise in predicting the dependent variable. The SEE value in table 4.3 (investment size) 0.086420 and in table 4.4 (asset allocation policy) 0.079527 . This shows that of the three simple regressions, the smallest error rate is the simple investment cost regression model, then followed by the asset allocation policy and the last is the investment size.

\section{a. Simple Regression Model}

To get a simple regression equation with theil method, the values of B and A must 
be known first. But first you must look for the value of bij to find out the value of B.

Table 4. Value of Investment Cost vs. Investment Performance

\begin{tabular}{|l|l|l|r|}
\hline No. & bij & No. & bij \\
\hline 1 & 2,74690965 & 24 & 1,807098966 \\
\hline 2 & 6,47179324 & 25 & $-3,140110125$ \\
\hline 3 & 4,00629154 & 26 & $-0,810013631$ \\
\hline 4 & 2,78684312 & 27 & $-3,98413629$ \\
\hline 5 & 3,07731034 & 28 & 1,190773504 \\
\hline 6 & 2,30804597 & 29 & 3,364979195 \\
\hline 7 & 3,15431116 & 30 & 2,407220876 \\
\hline 8 & 3,74642007 & 31 & 13,61662388 \\
\hline 9 & 3,01559932 & 32 & $-6,691093149$ \\
\hline 10 & 7,17283962 & 33 & 5,09629911 \\
\hline 11 & 4,1585509 & 34 & 6,179442774 \\
\hline 12 & 2,79076631 & 35 & 3,20947582 \\
\hline 13 & 3,10881631 & 36 & $-28,51603321$ \\
\hline 14 & 2,26731085 & 37 & 3,643745051 \\
\hline 15 & 3,18744909 & 38 & 5,62068909 \\
\hline 16 & 3,81493729 & 39 & 2,960570901 \\
\hline 17 & 3,02709711 & 40 & 9,707058349 \\
\hline 18 & $-1,255925$ & 41 & 8,186445869 \\
\hline 19 & $-1,9946242$ & 42 & 3,676997418 \\
\hline 20 & $-1,0649607$ & 43 & 7,178374667 \\
\hline 21 & $-2,5061927$ & 44 & 2,849088875 \\
\hline 22 & 0,15403331 & 45 & 1,71828338 \\
\hline 23 & 1,89119025 & & \\
\hline
\end{tabular}

(Source: Data Processed (2020))

Table 5. Value b ij investment size vs. Investment Performance

\begin{tabular}{|l|r|r|r|}
\hline No. & bij & No. & bij \\
\hline 1 & 0,19338032 & 24 & $-0,069845$ \\
\hline 2 & 1,38522504 & 25 & 1,385225 \\
3 & 0,85716654 & 26 & 0,8571665 \\
4 & 0,8719253 & 27 & 0,8719253 \\
\hline 5 & 0,85288974 & 28 & 0,8528897 \\
\hline 6 & 0,41618842 & 29 & 0,4161884 \\
\hline 7 & 0,25096278 & 30 & 0,2509628 \\
\hline 8 & 0,27020018 & 31 & 0,2702002 \\
\hline 9 & 0,28380902 & 32 & 0,283809 \\
10 & 2,43889398 & 33 & 2,438894 \\
\hline 11 & 1,1808696 & 34 & 1,1808696 \\
\hline 12 & 1,0545721 & 35 & 1,0545721 \\
13 & 0,98308022 & 36 & 0,9830802 \\
14 & 0,45388026 & 37 & 0,4538803 \\
\hline 15 & 0,25965742 & 38 & 0,2596574 \\
\hline 16 & 0,28099416 & 39 & 0,2809942 \\
\hline 17 & 0,29544972 & 40 & 0,2954497 \\
\hline 18 & $-0,3667692$ & 41 & $-0,366769$ \\
\hline 19 & 0,44857287 & 42 & 0,4485729 \\
\hline 20 & 0,56455469 & 43 & 0,5645547 \\
\hline 21 & $-0,0158359$ & 44 & $-0,015836$ \\
22 & $-0,1892114$ & 45 & $-0,189211$ \\
\hline 23 & $-0,1267861$ & & \\
\hline 10 & &
\end{tabular}

(Source: Data Processed (2020))

Table 6. Value b ij of Asset Allocation Policy vs. Investment Performance 


\begin{tabular}{|l|r|r|r|}
\hline No. & bij & No. & bij \\
\hline 1 & $-0,000000065289$ & 24 & $-0,00000047240$ \\
2 & 0,000001850947 & 25 & 0,00000348473 \\
3 & $-0,000001249122$ & 26 & 0,00000015720 \\
4 & $-0,000000068301$ & 27 & 0,00000165003 \\
5 & $-0,000000290325$ & 28 & $-0,00000050242$ \\
\hline 6 & 0,000000791116 & 29 & 0,00000013886 \\
\hline 7 & $-0,000000636298$ & 30 & $-0,00000021262$ \\
8 & $-0,000000093155$ & 31 & $-0,00000045375$ \\
9 & $-0,000000309289$ & 32 & 0,00000135158 \\
10 & 0,000002711377 & 33 & $-0,00000081457$ \\
11 & $-0,000000926528$ & 34 & $-0,00000010028$ \\
12 & 0,000000252943 & 35 & $-0,00000034348$ \\
13 & $-0,000000166038$ & 36 & 0,00001537909 \\
14 & 0,000000936006 & 37 & $-0,00000108279$ \\
15 & $-0,000000572789$ & 38 & 0,00000012502 \\
16 & $-0,000000025774$ & 39 & $-0,00000031715$ \\
17 & $-0,000000273762$ & 40 & $-0,00000282435$ \\
\hline 18 & $-0,000010689520$ & 41 & $-0,00000123806$ \\
19 & $-0,000002561285$ & 42 & $-0,00000081482$ \\
20 & $-0,000000964883$ & 43 & 0,00000738647 \\
21 & 0,000000486899 & 44 & 0,00000004518 \\
22 & $-0,000001024392$ & 45 & $-0,00000058206$ \\
23 & $-0,000000373007$ & & \\
\hline
\end{tabular}

(Source: Data Processed (2020))

The formula used to find the value of B is as follows:

1. Investment Cost

$$
B=\underline{b}_{45+1}=b_{23}=3,015599316
$$

2

2. Ukuran Investasi

$$
B=\underline{b}_{45+1}=b_{23}=0,416188423
$$

$$
2
$$

3. Kebijakan Alokasi Aset

$$
B=\frac{b_{45+1}}{2}=b_{23}=-0,00000027376
$$

After the estimator $\mathrm{B}$ has been obtained, the regression equation takes the form:

$$
Y_{i}=A+B x
$$

To find out the value of $A$, substitution of $A$ with $\mathrm{Di}$ is carried out, so that the equation is obtained:

$$
\mathbf{Y}_{\mathbf{i}}=\mathbf{D}_{\mathbf{i}}+\mathbf{B} \mathbf{X}_{\mathbf{i}}
$$

From the above equation, the value of $\mathrm{Di}$ is produced as shown in the table below

Table 7.Value Di of Investment Cost vs. Investment Performance 


\begin{tabular}{|r|r|r|}
\hline \multicolumn{1}{|c|}{$\mathbf{X}$} & \multicolumn{1}{c|}{$\mathrm{Y}$} & \multicolumn{1}{c|}{$\mathrm{D} \boldsymbol{i}=\mathrm{Y} \boldsymbol{i}-\mathbf{B} \boldsymbol{x} \boldsymbol{~}$} \\
\hline 0,03126984 & 0,055239294 & $-0,039058018$ \\
0,03540569 & 0,066600108 & $-0,040169279$ \\
0,0573808 & 0,224224043 & 0,051186531 \\
0,06961455 & 0,208859375 & $-0,001070213$ \\
0,07750383 & 0,184086167 & $-0,04963433$ \\
0,07877806 & 0,201436811 & $-0,036126238$ \\
0,0799637 & 0,167626955 & $-0,07351152$ \\
0,08625235 & 0,228671222 & $-0,031431294$ \\
0,09573838 & 0,296765514 & 0,008056927 \\
0,13205563 & 0,359168838 & $-0,039058018$ \\
\hline
\end{tabular}

(Source: Data Processed (2020))

Table 8. Value Di of Investment Size vs. Investment Performance

\begin{tabular}{|r|c|c|}
\hline \multicolumn{1}{|c|}{$\mathbf{X}$} & $\mathbf{Y}$ & $\mathbf{D} \boldsymbol{i}=\mathbf{Y} \boldsymbol{i}-\mathbf{B x i}$ \\
\hline 7,326414887 & 0,055239294 & $-2,99392976$ \\
7,385163443 & 0,066600108 & $-3,00701942$ \\
7,73244432 & 0,167626955 & $-3,05052685$ \\
7,505633364 & 0,184086167 & $-2,93967154$ \\
7,803271989 & 0,201436811 & $-3,04619465$ \\
7,841541273 & 0,208859375 & $-3,05469932$ \\
7,7742409 & 0,224224043 & $-3,01132502$ \\
7,451616153 & 0,228671222 & $-2,87260515$ \\
7,603418228 & 0,296765514 & $-2,86768913$ \\
7,682767567 & 0,359168838 & $-2,83831008$ \\
\hline
\end{tabular}

(Source: Data Processed (2020))

Table 8. Value Di of Asset Allocation Policy vs. Investment Performance

\begin{tabular}{|c|r|r|}
\hline $\mathbf{X}$ & \multicolumn{1}{|c|}{$\mathbf{Y}$} & $\mathrm{D} \boldsymbol{i}=\mathbf{Y} \boldsymbol{i}-\mathbf{B x i}$ \\
\hline 299079,3833 & 0,228671222 & 0,310547908 \\
303447,0587 & 0,208859375 & 0,291931766 \\
335868,2778 & 0,296765514 & 0,388713615 \\
347949,1344 & 0,167626955 & 0,262882341 \\
364190,5789 & 0,224224043 & 0,323925725 \\
452648,6519 & 0,184086167 & 0,308004342 \\
464033,1171 & 0,359168838 & 0,486203651 \\
571643,5266 & 0,055239294 & 0,21173379 \\
591436,1325 & 0,201436811 & 0,363349778 \\
823092,1027 & 0,066600108 & 0,291931766 \\
\hline
\end{tabular}

(Source: Data Processed (2020))

After being sorted, we get the value of A which is the median of Di as follows:

1) Investment Cost

$$
A=\frac{D_{10+1}}{2}=D_{5,5}=\frac{(-0,04963433)+(-0,036126238)}{2}=-0,04288028
$$

2) Investment Size

$$
A=\frac{D_{10+1}}{2}=D_{5,5}=\frac{(-3,007019417)+(-2,993929762)}{2}=-3,000475
$$

3) Asset Alocation Policy

$$
A=\frac{D_{10+1}}{2}=D_{5,5}=\frac{0,308004342+0,310547908}{2}=0,309276125
$$


So we get the regression equation model as follows:

1. Investment Cost for Investment Performance of Hajj Funds in Malaysia $Y i=-0,042880284+3,015599316 X i$

2. Investment Size on Investment Performance of Hajj Funds in Malaysia $Y_{i}=-3,000474589+0,416188423 X_{i}$

3. Asset Allocation Policy on Investment Performance of Hajj Funds in Malaysia $Y_{i}=0,309276125+\left(-0,000000274 X_{i}\right)$

\section{b. Significant Test}

The regression model above cannot be said to be the best regression model if a significant test has not been performed to find out whether the regression model has a significant effect or not.

Table 9.Kendall Tau Correlation Value Investment Cost vs. Investment Performance

\begin{tabular}{lll|r|r} 
& & \multicolumn{1}{c}{$\begin{array}{c}\text { Kinerja } \\
\text { Investasi }\end{array}$} & $\begin{array}{c}\text { Investment } \\
\text { Cost }\end{array}$ \\
\hline Kendall's tau_b & Kinerja Investasi & Correlation Coefficient & 1,000 &, $600^{*}$ \\
\cline { 3 - 5 } & & Sig. (2-tailed) & 10 &, 016 \\
\cline { 3 - 5 } & $\mathrm{N}$ &, $600^{*}$ & 1,000 \\
\cline { 2 - 5 } & Investment Cost & Correlation Coefficient &, 016 & \\
\cline { 3 - 5 } & Sig. (2-tailed) & 10 & 10 \\
\hline & $\mathrm{N}$ & & \\
\hline
\end{tabular}

*. Correlation is significant at the 0.05 level (2-tailed).

(Source: SPSS 25 Output Results (2020))

Based on the table above it is known that the value of $T$ investment cost on investment performance is 0.6 and value

$$
\text { бт }=\sqrt{\frac{2(2.10+5)}{9.10(10-1)}}=\sqrt{\frac{2(25)}{90(9)}}=\sqrt{\frac{50}{810}}=\sqrt{0,0617}=0,248
$$

In order to obtain the $z$ value for investment cost on investment performance as follows.

$$
\begin{aligned}
& z=T-\mu_{T}=0,6-0=2,419 \\
& \text { бт } 0,248 \\
& p_{z}=0,5-P(z=2,419)=0,5-0,4922=0,0078 \quad a / 2=0,025
\end{aligned}
$$

Table 10.Kendall Tau Correlation Value Investment Size vs. Investment Performance

\begin{tabular}{lllr|r} 
& & \multicolumn{1}{c}{$\begin{array}{c}\text { Kinerja } \\
\text { Investasi }\end{array}$} & \multicolumn{1}{c}{$\begin{array}{c}\text { Ukuran } \\
\text { Investasi }\end{array}$} \\
\hline Kendall's tau_b & Kinerja Investasi & Correlation Coefficient & 1,000 &, 156 \\
\cline { 3 - 5 } & & Sig. (2-tailed) & 10 &, 531 \\
\cline { 3 - 5 } & $\mathrm{N}$ & 156 & 1,000 \\
\cline { 3 - 5 } & Ukuran Investasi & Correlation Coefficient &, 531 & \\
\cline { 3 - 5 } & Sig. (2-tailed) & 10 & 10 \\
\cline { 3 - 5 } & $\mathrm{N}$ & & 10 \\
\hline
\end{tabular}

(Source: SPSS 25 Output Results (2020)) 
Based on the table above it is known that the value of investasi investment size on investment performance is 0.156 and value

$$
\sigma_{\mathrm{T}}=\sqrt{\frac{2(2.10+5)}{9.10(10-1)}}=\sqrt{\frac{2(25)}{90(9)}}=\sqrt{\frac{50}{810}}=\sqrt{0,0617}=0,248
$$

In order to obtain the $\mathrm{z}$ value for investment size on investment performance as follows.

$$
\begin{aligned}
& z=T-\mu_{T}=0,156-0=0,629 \\
& \sigma_{\text {T }} 0,248 \\
& p_{z}=0,5-P(z=0,629)=0,5-0,2357=0,2643 \quad a / 2=0,025
\end{aligned}
$$

Table 11.Kendall Tau Correlation Value Asset Alocation Policy vs. Investment Performance

\begin{tabular}{lll|r|r} 
& & \multicolumn{1}{c}{$\begin{array}{c}\text { Kinerja } \\
\text { Investasi }\end{array}$} & $\begin{array}{c}\text { Kebijakan } \\
\text { Alokasi Aset }\end{array}$ \\
\hline Kendall's tau_b & Kinerja Investasi & Correlation Coefficient & 1,000 &,- 333 \\
\cline { 3 - 5 } & Sig. (2-tailed) &. &, 180 \\
\cline { 2 - 5 } & $\mathrm{N}$ & 10 & 10 \\
\cline { 2 - 5 } & Kebijakan Alokasi Aset & Correlation Coefficient & -333 & 1,000 \\
\cline { 3 - 5 } & Sig. (2-tailed) &, 180 & \\
\cline { 3 - 5 } & $\mathrm{N}$ & 10 & 10 \\
\hline
\end{tabular}

(Source: SPSS 25 Output Results (2020))

Based on the table above it is known that the value of the policy on asset allocation to investment performance is -0.333 and value

$$
\text { бт }=\sqrt{\frac{2(2.10+5)}{9.10(10-1)}}=\sqrt{ } \frac{2(25)}{90(9)}=\sqrt{ } \frac{50}{810}=\sqrt{0,0617}=0,248
$$

In order to obtain the $\mathrm{z}$ value for the asset allocation policy on investment performance as follows.

$$
\begin{aligned}
& z=T-\mu_{T}=0,333-0=1,342 \\
& \sigma_{T} \quad 0,248 \\
& p_{z}=0,5-P(z=1,342)=0,5-0,4099=0,0901 \quad \alpha / 2=0,025
\end{aligned}
$$

Because the probability of investment cost $(0.0078)$ is less than 0.025 , it can be said that investment cost has a significant effect on the investment performance of haj funds in Malaysia. This is consistent with the results of research by Bitomo and Muharam (2016)which states that costs show a positive relationship on investment performance, the more costs incurred, the investment performance will increase (Bitomo and Muharam 2016).

The probability value of the investment size $(0.2643)$ is greater than 0.025 so it can be said that the size of the investment has no significant effect on the investment performance of the pilgrimage fund in Malaysia. This means that scientifically the size of the investment does not convince the truth in terms of influence on the investment performance of Hajj funds in Malaysia. So it can be said that the size of assets cannot predict future investment performance. The results of this study differ from the theory 
in Prihadi (2009) which states that size influences investment decision making (Prihadi 2009).

For the probability of asset allocation policy $(0.0901)$ is greater than 0.025 , it can be interpreted that the asset allocation policy does not significantly influence the investment performance of hajj funds in Malaysia. This means that the asset allocation policy undertaken cannot predict future investment performance because insignificant results cannot be convinced. In contrast to the results of Paramitha and Purnawati(2017) which shows that asset allocation policies have a significant positive effect on the performance of equity funds in Indonesia (Paramitha and Purnawati 2017).

\section{Conclusion and Recommendation}

From the results of testing, analysis and discussion it was found that the investment cost partially had a significant positive effect on the investment performance of the hajj funds in Malaysia. While the size of the investment does not have a significant positive effect on the investment performance of haj funds in Malaysia. Likewise, the partial asset allocation policy has no significant positive effect on the investment performance of haj funds in Malaysia. Based on this, a large amount of Investment Cost if managed properly will improve the investment performance of the pilgrimage fund. However, the larger the size of the investment, the more complex it will be to manage the funds to be allocated to the types of investment available. So we need good management skills to produce good investment performance. In the asset allocation policy, the allocation of types of investment that are less appropriate to the ongoing economic cycle causes suboptimal income.

\section{References}

[1]"Antrean Masa Tunggu Haji Di Malaysia Hingga 121 Tahun (The Queve Waiting Period for Pilgrimage in Malaysia to 121 Years)." 2019. Ministry of Religion. 2019. https://haji.kemenag.go.id/v3/content/antrean-masa-tunggu-haji-di-malaysiahingga-121-tahun.

[2]Aziz, Abdul. 2010. "Manajemen Investasi Syariah (Sharia Investment Management)." Bandung: Alfabeta.

[3]Bitomo, Habib, and Harjum Muharam. 2016. "Analisis Faktor-Faktor Yang Mempengaruhi Kinerja Reksa Dana Di Indonesia (Studi Empiris Pada Reksa Dana Konvensional Di Indonesia Periode 2012-2014)." Fakultas Ekonomika dan Bisnis.

[4]Darmasto, Bonifatius, Kamaliah Kamaliah, and Restu Agusti. n.d. "Analisis Pengukuran Kinerja Perusahaan Dengan Metode Balanced Scorecard (Studi Pada PT XI Axiata Tbk-Jakarta)." Sorot 9 (1): 70-85.

[5]Fatwa Nasional Sharia Council - Indonesian Ulema Council No: 07/DSN-MUI/IV/2000 about Mudharabah Financing (Qiradh). 2000. www.mui.or.id. http://mui.or.id/wp-content/uploads/files/fatwa/07-Mudharabah.pdf.

[6]Indonesia Law No. 34. 2014. Indonesia.

[7]"Jumlah Populasi Muslim Dunia (Total World Muslim Population)." 2019. Media Indonesia. 2019. https://mediaindonesia.com/read/detail/233627-jumlahpopulasi-muslim-dunia.

[8] Kasmir. 2010. Analisis Laporan Keuangan (Financial Statement Analysis). Jakarta: Raja Grafindo Persada.

[9]Malaysia Law: Akta 535 "Akta Tabung Haji 1995." 2014. Kuala Lumpur: Percetakan Nasional Malaysia Berhad.

[10]Nadjib, Mochammad. 2008. "Investasi Syari'ah Implementasi Konsep Pada Kenyataan Empirik." Yogyakarta: Kreasi Wacana.

[11]Nugraha, Robi. 2016. "ANALYSIS OF THE INFLUENCE OF CAPITAL LABOUR INTENSIVE, 
INVESTMENT, MANAGERIAL OWNERSHIP, OPERATING LEVERAGETHROUGH DIVIDEND AND FINANCIAL LEVERAGE AS INTERVENING VARIABLE ON FIRM VALUE IN INDONESIA NON FINANCIAL SECTOR COMPANIES." JRMSI-JUrnal Riset Manajemen Sains Indonesia 7 (1): 1-21.

[12]Nurtjahjo, F. 2013. "Pengelolaan Akuntabilitas Sektor Publik (Management of Public Sector Accountability)." Jakarta.

[13]Paramitha, A A Sagung Putra Pradnya, and Ni Ketut Purnawati. 2017. "Pengaruh Kinerja Manajer Investasi Dan Kebijakan Alokasi Aset Terhadap Kinerja Reksa Dana Saham Di Indonesia (Effect of Investment Manager Performance and Asset Alocation Policy on the Performance of Equity Funds in Indonesia)." EJurnal Manajemen 6 (8): 4019-47.

[14]Peristiwo, Hadi. 2016. "Analisis Minat Investor Di Kota Serang Terhadap Investasi Syariah Pada Pasar Modal Syariah (Analysis of Investor Interest in Serang City Toward Sharia Investment in the Sharia Capital Market)." ISLAMICONOMIC: Jurnal Ekonomi Islam 7 (1).

[15]Pratomo, Eko Priyo. 2001. Reksa Dana: Solusi Perencanaan Investasi Di Era Modern (Mutual Funds: Investment on Planning Solution in the Modern Era). Gramedia Pustaka Utama.

[16]Prihadi, Toto. 2009. "Investigasi Laporan Keuangan \& Analisis Rasio Keuangan (Financial Report Investigation \& Financial Ratio Analysis)." Jakarta. PPM Manajemen.

[17]Putra, A. A. B. 2014. "Analisis Dan Faktor Penentu Kinerja Reksa Dana Saham (Analysis and Determinants of Performance of Equity Funds)." Universitasi Is/am Indonesia. https://doi.org/https://doi.org/10.1016/j.cell.2009.01.043.

[18]Rahmatina, DESI. 2011. "Analisis Regresi Linear Pada Statistika Non Parametrik." Jurnal Ekonomi. HIm, 1-16.

[19]Reilly, Frank K, and Keith C Brown. 2011. Investment Analysis and Portfolio Management. Cengage Learning.

[20]Ruhiyat, Endang. 2016. "'Tantangan Pengembangan IImu Akutansi, Inklusi Keuangan, Dan Kontribusinya Terhadap Pembangunan Ekonomi Berkelanjutan.' In Pengaruh Ukuran Dana Kelolaan, Umur Reksa Dana, Dan Biaya Operasi Reksa Dana Terhadap Kinerja Reksa Dana Saham ("The Challenges of D." In , 118-63.

[21] Salatalohy, Hasmiati Arsiba, and Hendro Wibowo. 2019. "Pengaruh Inflasi Dan BI Rate Terhadap Imbal Hasil Penyaluran Investasi Dana Haji Pada Sukuk Dana Haji Indonesia (The Influence of Inflation and The BI Rate on Returns on the Distribution of Hajj Fund Investment in Indonesian Hajj Sukuk)." Jurnal Kordinat 18 (1): 119-57. https://doi.org/https://doi.org/10.1192/bjp.112.483.211-a.

[22]Subramanyam, K R, and John J Wild. 2010. "Analisis Laporan Keuangan (Financial Statement Analysis)." Jakarta: Salemba Empat.

[23]Sudirman. 2015. "Pasar Modal Dan Manajemen Portofolio." Gorontalo: Sultan Amai Press. 2015. https://www.researchgate.net/publication/322696132.

[24]"Tabung Haji Malaysia: Penyimpan Dana Ibadah Haji Profesional Dan Berintegritas (Malaysian Hajj Tube: Professional and Integrity Pilgrimage Fund Depositors)." $2017 . \quad$ Muslim 2017. https://www.gomuslim.co.id/read/korporasi/2017/01/14/2883/tabung-hajimalaysia-penyimpan-dana-ibadah-haji-profesional-dan-berintegritas.html.

[25]Tandelilin, Eduardus. 2010. Portofolio Dan Investasi: Teori Dan Aplikasi (Portofolios and Investments: Theory and Application). Kanisius.

[26]Zandra, Rosy Aprieza Puspita. 2016. "Pengaruh Biaya Operasional Dan Perputaran Persediaan Terhadap Profitabilitas (Effect of Operational Costs and Inventory Turnover on Profitability)." JURNAL AKUNTANSI DAN INVESTASI 1 (1): 93-107. 